\title{
Vladimir Propp ve Biçimbilimsel Çözümleme Yöntemi: Being There Filmi Üzerine Bir Analiz
}

Vladimir Propp and the Morphological Analysis Method: An Analysis of Being There

\section{Araştırma Makalesi / Research Article}

\section{Sorumlu yazar/ Corresponding author: ilknur Patan}

ORCID: 0000-0002-6534-6892

Geliş tarihi/Received: 11.10 .2021

\section{Son revizyon tarihi/Last revision received: 27.11.2021}

\section{Kabul tarihi/Accepted:}

28.11.2021

\section{Yayın tarihi/ Published:}

09.12 .2021

\section{Atıf/Citation:}

Patan, İ. (2021). Vladimir Propp ve biçimbilimsel çözümleme yöntemi: Being There filmi üzerine bir analiz. iletişim ve Diplomasi,

6, 51-77.

doi:

10.54722/iletisimvediplomasi.1007558

\section{İlknur PATAN'®}

\section{öz}

Vladimir Propp göstergebilimden halkbilime, budunbilimden dilbilime birçok alanda çalışmalar yapan önemli bir araştırmacı ve dilbilimcidir. Ancak ona bugünkü ününü kazandıran çalışması Masalın Biçimbilimi isimli yapıtıdır. Propp, bu yapıtında hem Rus masallarını incelemiş ve yapılarına göre sınıflandırmış hem de anlatı çözümlemeleri açısından birçok araştırmacıya referans olan ve günümüzde de güncelliğini koruyan bir yöntem geliştirmiştir. Propp geliştirdiği bu yöntem ile sözlü gelenek ürünü olan masalların çözümlemesini mümkün kılmıştır.

Günümüzde görsel, işitsel ve dijital iletişim alanında yaşanan gelişmelerle birlikte yazınsal yapıtlar yoğun olarak sinemaya uyarlanmaktadır. Bu çalışma, sinemaya uyarlanan bir romanın biçimbilimsel çözümlemesi yapılabilir mi sorusu üzerine şekillenmiştir. Çünkü son yıllarda bilinen birçok masalın geleneksel ve modern bakış açılarıyla sinema uyarlaması bulunmaktadır. Bu bağlamda, Propp'un biçimbilimsel çözümleme yapmak için geliştirmiş olduğu 31 işlev ve 7 eylem alanından oluşan yönteminin sinema filmi analizi için kullanılması çaıışmanın yöntemini oluşturmaktadır. Çalışmanın konusunu bir romandan uyarlanmış olan Being There isimli sinema filminin Propp'un biçimbilimsel çözümleme yöntemi ile inceIenmesi oluşturmaktadır. Elde edilen veriler incelendiğinde Propp'un biçimbilimsel çözümleme yönteminde bulunan

Öğr. Gör., Tokat Gaziosmanpaşa Üniversitesi Niksar Meslek Yüksekokulu, Pazarlama ve Reklamcılık Bölümü, Tokat, Türkiye, ilknurpatan3@gmail.com 
işlev ve eylem alanlarının Being There filminde yer aldığı görülmektedir. Propp'un yönteminde belirttiği en önemli kriter bu işlev ve eylemlerin birbirini takip eden bir olay örgüsü içerisinde gerçekleşmesi gerektiğidir. Being There filminde işlev ve eylemlerin sıralaması karışıktır. Bu yüzden filmde bulunan işlev ve eylemler yönteme yönelik beklentileri karşılamamaktadır.

Anahtar Kelimeler: Vladimir Propp, masal biçimbilimi, biçimbilimsel çözümleme, sinema, Being There

\section{ABSTRACT}

Vladimir Propp is a leading researcher and linguist who works in a variety of fields, from semiotics to folklore, from ethnology to linguistics. The Morphology of the Tale, on the other hand, is the work that has made him renowned today. In this work, Propp not only investigated Russian fairy tales and categorised them according to their structures but also devised a method that is a reference to many researchers in terms of narrative analysis and is still up-to-date today. With this method he developed, Propp made it possible to analyse the tales that are the product of oral tradition.

Today, with the developments in the field of audio, visual and digital communication, literary works are intensively adapted to cinema. This study is shaped on whether a novel adapted to the cinema can also be analysed morphologically. Because in recent years, many well-known stories have been adapted into films with both traditional and modern views. In this context, the use of Propp's method, which consists of 31 functions and 7 action areas, developed for morphological analysis, for movie analysis constitutes the method of the study. The subject of the study is the examination of the movie Being There, which is adapted from a novel with Propp's morphological analysis method. When the data obtained are evaluated, it is seen that the function and action areas in Propp's morphological analysis method are included in the movie Being There. The most important criterion stated by Propp in his method is that these functions and actions must take place in a sequence of events. In the movie Being There, the order of functions and actions is jumbled. Therefore, the functions and actions in the film do not meet the expectations for the method.

Keywords: Vladimir Propp, morphology of folktale, morphological analysis, cinema, Being There 


\section{EXTENDED ABSTRACT}

Developing a method for structural analysis, Propp created this method by analysing only extraordinary tales that are short. Tales are anonymous products belonging to certain nations in the oral tradition, and it is not clear who created them. According to Propp, although there are very rich and colourful contents in a fairy tale, uniformity prevails as a structure. The concept of uniformity aims to explain that tales have a certain function and field of action and that the skeleton is the same even though the subject is different.

The analysis method is used very frequently in the field of social sciences. Literary text analysis, semiotic analysis based on signs, structural analysis in form and content are only a few. The products handled while using the analysis method show quite a variety. For example, using the analysis method, TV series, movies, advertisements, music, pictures, books, posters and news are analysed. Major developments in communication technologies are the biggest factor in the diversity of the products analysed. Especially with the emergence of audio-visual tools such as television, cinema and radio, literary works have begun to be transmitted to individuals and society through these tools. This situation may be seen in the narrative radio broadcasts and the adaptation of numerous literary masterpieces to television and film.

Propp limited his method of morphological analysis only to the study of extraordinary tales. In this method, there are 31 functions that are thought to constitute a literary product and 7 action fields belonging to the heroes. According to Propp, although the subject, heroes and events of the tales vary, their structural analysis and plot are similar. Over time, researchers have begun to question whether these functions and fields of action could be used in the analysis of movies, TV series and advertisements. Many studies have been done on this, while some analyses are compatible with Propp's morphological method, some studies are not compatible with this method.

The morphological analysis of the film Being There, which was chosen as a sample, was done in accordance with this information. Propp's 31 functions and 7 action fields were used as a starting point for the analysis. The existence of 28 functions and 7 action fields connected to Propp's morphological analysis approach was determined during the study of the film Being There. Accordingly, 3 of the 31 functions found in the morphological analysis method in the film are missing. However, Propp stated that sometimes one or more of the functions might be missing, which would not pose a problem in terms of morphology. The main problem here is in the order of functions. Propp is quite clear that although there are deficiencies in the functions he has determined, the order of the functions will not change. Although there are 28 functions in the examined film, these functions do not occur sequentially and are in a mixed structure. For example, a function that is in the last place in Propp's method appears in 
the first place in the movie. This reveals a situation that contradicts the morphological analysis method.

The films depict a feature that appeals to the taste of popular culture. The message that should be conveyed last is sometimes observed in the first scenes of the movie. In this case, the scenario demonstrates diversity and variation rather than uniformity. Although there are various functions and fields of action in the study, it is feasibleto state that the expectations for the method are not fully realised. The most important factor in not meeting the expectations is the emphasis on invariance in the function order of the method. The study has many functions and fields of action, but they do not appear in a fixed order. As a result, while Propp's morphological analysis may be used in films, the order of functions, which is a key characteristic, does not always meet expectations.

\section{Giriş}

Belirli bir konuda görüş ve fikir oluşturmak için 'çözümleme yapmak' kavramı kullanılmaktadır. Çözümlemek, bir konuyu analiz etmek, sonuca bağlamak gibi anlamlara gelmektedir. Multidisipliner alanların varlığı düşünüldüğünde birçok çözümleme yöntemi bulunmaktadır. Yapısal inceleme yapan 'biçimbilimsel çözümleme' bunlardan yalnızca biridir. Biçimbilimsel çözümleme, karmaşık yapıdaki bir nesnenin daha kolay anlaşıımasını sağlamak için onu işlevlerine ve temel birimlerine ayırarak incelemektedir. Propp'un oluşturduğu yöntem de tam olarak bunu amaçlamaktadır. Propp, çok çeşitli ve karışık gibi görünen masalların aslında belli başlı işlevlere göre şekillendiğini, konular ve kahramanlar değişse bile işlevlerin aynı kaldığını öne sürmektedir. Bu görüşünü Rus masallarının biçimbilimsel çözümlemesini yaptığı Masalın Biçimbilimi yapıtında temellendirmiştir.

Propp'un, çeşitli sınıflandırması yapılan (hayvan masalları, eğlendirici masallar, gerçekçi masallar, olağanüstü masallar) masal türleri arasından olağanüstü masallar üzerine çalıştığı bilinmektedir. Sözlü gelenek ürünü olan masallar, geçmişte anonim özellik göstermesine rağmen, derlenerek yazılı geleneğe aktarılmıştır. Rus biçimbilimci olan Propp'a kadar kimse masalların yapısal bir incelemesini yapmayı düşünmemiştir. Bu anlamda Propp ilk olma özelliği göstermesine rağmen eserini yayınladığı dönemlerde bu yöntem çok dikkat çekmemiştir. Sonraki yıllarda eserin farklı dillere çevrilmesi, dilbilimi ve göstergebilimi alanında çalışma yapan araştırmacıların yöntemden haberdar olmasına ortam hazırlamış ve yöntem, çağdaş araştırmacılar tarafından büyük ilgi görmüştür. Bazı araştırmacılar Propp'un ilk olma özelliğini göz önünde bulundurarak yapıcı eleştirilerle yöntemin geliştirilmesine katkıda bulunmuştur.

Propp yöntemini yalnızca olağanüstü masallarla sınırlı tutmuştur ancak zamanla bu yöntemin farklı alanlarda kullanılıp kullanılmayacağı üzerine ulusal ve uluslararası 
çalışmalar yapılmıştır. Güngör Kılıç (2018) “Farklı yüzyıllar aynı biçimler: V. Propp'un İşlevsel Yaklaşımı Çerçevesinde Alacakaranlık Film Serisi Üzerine Bir Çözümleme ve Kitle Kültürü Sineması Eleştirisi", Çakır (2017) "Yeşilçam Sineması ve Masal Formu: Ayşecik", Şimşek (2012) Los Angeles"da Bir Külkedisi: Propp"a Göre Bir Film Çözümlemesi, Doğan (2018) "Türk Sinemasında Masal Uyarlamaları ve Vladimir Propp'un Halk Masalları İşlevlerinin Pamuk Prenses ve Yedi Cüceler (1970) Filminde Çözümlenmesi" ve Lahlou (2017) "An Attempt at Applying Vladimir Propp's Morphology of the Folktale on Charles Dickens's Great Expectations" isimli çalışmalar Propp'un analiz yöntemiyle incelenmiştir. Bu kapsamda yazınsal metinlerin analizi için geliştirilen bir yöntemin sinemada uygulanıp uygulanamayacağı sorusundan yola çıkılarak yapılan çalışma da Jerzy Kosiński'nin kaleme aldığı Being There isimli yazınsal yapıtın sinema filmi, Propp'un biçimbilimsel çözümleme analiziyle incelenmiştir.

\section{Propp ve Masalın Biçimbilimi Yazınsal Çözümleme Yöntemi}

Yapısalcılık ve biçimcilik² yirminci yüzyılın ilk yarısında edebiyat eleştirisi, dilbilimi ve sosyal bilimlerde kullanılmaya başlanmıştır. Zamanla yapısal ve biçimsel incelemeler, atasözleri, bilmeceler, türküler ve ilahiler gibi türleri kapsayan birçok inceleme alanına yayılmıştır (Ben Amos, 1972, s. 125).

1915-1930 yılları arasında biçimcilik, Moskova Dilbilimi Çevresi ve Şiirsel Dil Araştırmaları Derneği'ne mensup araştırmacıların çabalarıyla şekillenmiştir. Rus biçimciliği ya da biçimcilik ismi bu çalışmaları yapan araştırmacılar tarafından belirlenmemiştir. Bu isim esasen onları ve çalışmalarını küçümseyen bir isimdir. Ancak kısa sürede elde ettikleri gelişmelerle bu çevreye mensup araştırmacıların yayınları önemli bir sayıya ulaşmış ve biçimcilere gösterilen ilgi artmıştır. Biçimcilerde çalışmalarını dilbiliminden çok yazın üzerine yoğunlaştırmaları bir kenara bırakıldığında Saussure'e çok yaklaşan bir tutum sergilediklerini söylemek mümkündür. Saussure gibi doğrudan nesnenin kendisini çoğunlukla eşzamanlık düzleminde ele almaktadır. Rus biçimciler nesnenin kendisini; eser yazarının yaşamı, ait olduğu toplum, çağ gibi kendi bağlamı dışında kalan verilerle açıklamayı uygun görerek her şeyden önce yazınsallık üzerinde durarak biçime önem vermişlerdir (Yücel, 2005, ss. 121-122). Propp'un çalışmalarını da bu kapsamda değerlendirmek mümkündür. Yapısal metin çözümleme yapmak için oluşturduğu yöntem, sonraki dönemlerde göstergebiliminin gelişmesinde ve farklı alanlara yönelmesinde etkili olmuştur (Rifat, 1998, s. 124). Ayrıca son yıllarda göstergebilimi alanında kullanılan kavram ve tekniklerin temelinde Rus biçimcilerin görüşleri önemli bir yer tutmaktadır (Propp, 1998, s. 153).

Biçimcilik/Biçimbilim, morfoloji, yapı bilgisi, şekil bilgisi ve biçim bilgisi gibi anlamlara gelmektedir. Bu kavram ile anlatılmak istenen şey bir dilin anlam taşıyan en küçük parçalarına odaklanmaktır. Örneğin Zooıoji alanının biçimbilimi hayvanların anatomisini, türleri arasındaki ilişkiyi ve bağlantılarını kapsamaktadır. 
Rus biçimci olan Vladimir Propp, anlatıbilim ile ilişkilendirilmektedir. Ancak Propp'un geliştirdiği yöntemde esas olarak bir metnin anlatı yapısıyla ilgili olan başka bir yapısalcılık biçimi hâkimdir (Dobie, 2012, ss. 156-157). Özellikle 1920'li ve 1930'lu yıllarda yaptığı çalışmalar, doğrudan göstergebilim kuramı içerisinde yer almasa da, anlatı yapılarının çözümlenmesi açısından büyük önem taşımaktadır (Rifat, 2009, s. 38). Anlatı çözümlemeleri değerlendirildiğinde, edebiyat incelemesi ve halkbilimi incelemesini aynı şeyler olarak gören Propp'a göre edebiyat ve halkbilimi yakın ilişkilere sahip olması nedeniyle özdeş sayılmaktadır. Eğer incelenen nesne dikkate alınmazsa edebiyat yöntemlerinin halkbilimde de kullanıldığı görülmektedir. Edebî çözümlemeler halkbilimi mazmunlarının yasalarını ve fenomenlerini keşfedebilir ancak açıklamakta yetersiz kalırlar. Edebî yapıt ile halkbilimi arasında belirgin ayrımlar bulunmaktadır. Bunlardan en önemlisi edebî ürünlerin yazarları vardır ancak halkbilimi ürünlerinde yazar yoktur. Bu eserler anonim özellik göstermektedir (Propp, 1998, s. 14).

Edebî yapıtlardan ziyade halkbilimi alanında metinsel incelemeler yapan Propp, kendisine ün kazandıran eserini 1928'de yayınlamasına rağmen dünya çapında tanınan bir biçimci olması ancak 1958 yılında gerçekleşmiştir. Çünkü Propp'un eseri bu yıllardan itibaren çeşitli dillere çevrilmiş ve birçok araştırmacı tarafından incelenmiştir. Öte yandan Propp'un tanınan bir biçimci olmasında etkili olan isimlerden birisi de Levi Strauss'tur. Yapısal Antropolojinin kurucusu olarak bilinen Fransız bilim insanı Claude Levi Strauss 1960 yılında kaleme aldığı "Structure and Form: Reflections on a Work by Vladimir Propp" isimli yazısında Propp'tan bahsetmektedir. Bu yazı eleştirel bir nitelik taşımaktadır (Propp, 1998, ss. 7-8).

Bu bağlamda Batılı dillerde eser kaleme almayan birçok araştırmacının başına geldiği gibi Propp'un eseri Fransa'da Levi Strauss'un ve ABD'de Alan Dundes'in bakış açısıyla algılanmıştır. Roland Barthes, Algirdas Greimas, Claude Bremond ve Tzvetan Todorov gibi önde gelen Fransız yapısalcı düşünürleri Levi-Strauss'un izinden giderek Propp'un yöntemini yazınsal göstergebilim bağlamında tartışıp geliştirmiştir. Aynı zamanda Propp'un eserini Dundes'in yazılarından öğrenen araştırmacılar ise Propp'un somut araştırmalarından çok Dundes'in geliştirdiği bu yeni yöntemle ilgilenmiştir (Propp, 1998, s. 8).

Yazınsal göstergebilim çerçevesinde araştırmacıların birçoğu derin yüzey çözümlemesinin dışına çıkmayarak yapıtın tamamının anlamsal içeriğini belirlemekle sınırlı kalmıştır. Bunun yanı sıra birçok göstergebilimci de Propp'un çalışmalarını benimseyerek araştırmalarını yüzeysel çözümleme yöntemiyle yapmış, yapıtların bağlantı ve işlevlerini incelemiştir (Yücel, 2005, s. 146).

Yapıtlardaki bağlantı ve işlevleri inceleyen Propp'a göre, biçimbiliminin sabit değişkenleri ve tek biçimli kuralları vardır ve yapıtlar bu kuralları barındırdığı sürece eşsüremli olarak kabul edilmektedir. Bu noktada masalın biçimbilimsel incelemesini yapanların temel kabulleri "kişi kendine masalın nereden geldiğini sormadan önce 
masalın nelerden oluştuğunu belirlemelidir" önermesiyle açıklanmaktadır (Cirese, 1982, ss. 34-36). Yapısalcılıktan ziyade biçimciliği önemseyen Propp'a göre masalın (yapıtın) kim tarafından yazıldığı, hangi millete ait olduğuna dair yapılan tarihsel incelemelerden önce betimleme sorununa değinilmesi gerekmektedir. Çünkü betimleme sorununa yönelik bir çalışma yapılmadan masalların doğuşundan söz etmek boşa çaba sarf etmektir. Masalın tarihsel incelenmesi aydınlatılmadan önce masalın ne olduğunun bilinmesi gerektiği önemli unsurdur (Propp, 2001, s. 20).

Masalların doğru bir betimlemesinin yapılmasının önemli olduğunu vurgulayan Propp bunu sağlayacak yöntemler üzerine düşünerek bunu bir örnekle açıklamıştır (Propp, 2001, s. 38):

1. "Kral, bir yiğide, bir kartal verir. Kartal, yiğidi, başka bir krallığa götürür (171).

2. Büyükbaba, Suçenko'ya bir at verir. At, Suçenko'yu başka bir krallığa götürür (132).

3. Bir büyücü, Ivan'a bir kayık verir. Kayık, Ivan'ı başka bir krallığa götürür (138).

4. Kraliçe, Ivan'a bir yüzük verir. Yüzükten çıkan iri yarı adamlar Ivan'ı başka bir krallığa götürürler (156), vb."

Yukarıda belirtilen durumlarda sabit değerler ve değişken değerlerin bulunduğu görülmektedir. Değişken değerler, karakterlerin isimleri ve özel nitelikleridir; sabit değişkenler ise kişilerin eylemleri ya da işlevleridir. Buna göre masallarda çoğunlukla aynı işlevler farklı kişiler tarafından gerçekleştirilmektedir (Propp, 2001, s. 38). Propp'un yönteminde işlev/fonksiyon ${ }^{3}$ kavramı çok sık kullanılmaktadır. Propp bu kavramı "bir kişinin eylemini, olay örgüsünün akışı içinde taşıdığı anlam" olarak kullanmaktadır (Propp, 2001, s. 40). Masal kahramanlarının eylemleri Propp'un masallarda 'olmazsa olmaz' dediği işlevleri meydana getirmektedir (Rifat, 2009, s. 39). Bu bağlamda işlevler eylem tiplerinin olay örgüsü içindeki konumlarına göre betimlenmektedir. Bu işlevlere verilen adlar anlatılardaki eylemlerle ilişkilendirilmektedir (Rifat, 2013, s. 115).

Propp, A. N. Veselovski'den esinlenerek anlatının temel ögelere (işlevler ve roller) nasıl bölüneceğini, bu temel ögelerin bir masal içerisinde nasıl bütünlük sağladığını ve tamamlandığını göstermek istemiştir (Todorov, 2014, s. 12). Propp, yapmış olduğu çalışmasını olağanüstü masallarla sınırlı tutup bunun dışında kalan masal türlerini çaIışmasına dâhil etmemiştir. Buna göre; Propp, A. N. Afanasyev'in derlediği "Rus Halk Masalları"nda 50 ile 150 numaralar arasında yer alan 100 adet masalın incelemesini yapmıştır (Bars, 2014, s. 84). Propp'un yöntemi, vurguyu hikâyenin olay örgüsüne ve zamansal sekanslarına yerleştirerek, olay örgüsünün gelişimini sıralı olaylara dayandırmaktadır (Stam et al., 1992, s. 102).

\footnotetext{
"Bir nesne veya bir kimsenin gördüğü iş, iş görme yetisi, görev, fonksiyon" olarak tanımlanırken; "Toplumbilimi terimi olarak işlev: Bir yapının gerçekleştirilebileceği ve onu başka yapılardan ayırt etme imkânı veren eylem türü, fonksiyon" anlamlarına gelmektedir (https://sozluk.gov.tr/ Erişim Tarihi: 04.07. 2021).
} 
Propp, yaptığı incelemeler sonucunda masalların çözümlenmesinde 31 işlev saptamıştır. Ona göre incelediği masallarda ve farklı uluslara ait olan birçok masalda olay örgüsü bu işlevler çerçevesinde gelişmektedir. Belirlenen 31 işlev sırasıyla okunduğunda kendi içerisinde bir bütünlük göstermektedir. Hiçbir işlev bir diğerini dışlamamakla birlikte tüm işlevler tek bir eksene bağlıdır (Propp, 2001, s. 88). Bu bilgiler doğrultusunda Propp'un masal çözümlemesine ait 31 işlev aşağıdaki gibi aktarılmaktadır (Propp, 2001, ss. 45-88):

\begin{tabular}{|c|c|c|c|}
\hline Numara & Sembol & Tanım & Açıklama \\
\hline 1 & B & "Uzaklaşma" & "Aileden biri evden uzaklaşır." \\
\hline 2 & $\Gamma$ & "Yasaklama" & "Kahraman bir yasakla karşılaşır." \\
\hline 3 & $\Delta$ & “Yasağı Çiğneme" & "Yasak çiğnenir." \\
\hline 4 & $\mathrm{E}$ & "Soruşturma" & "Saldırgan bilgi edinmeye çalışır." \\
\hline 5 & Z & "Bilgi Toplama" & "Saldırgan kurbanıyla ilgili bilgi toplar." \\
\hline 6 & N & "Aldatma" & $\begin{array}{l}\text { "Saldırgan, kurbanını ya da servetini ele } \\
\text { geçirmek için, onu aldatmayı dener." }\end{array}$ \\
\hline 7 & $\Theta$ & "Suça Katılma" & $\begin{array}{l}\text { "Kurban aldanır ve böylece istemeyerek } \\
\text { düşmanına yardım etmiş olur." }\end{array}$ \\
\hline 8 & A & “Kötülük” & "Saldırgan aileden birine zarar verir." \\
\hline $8 \mathrm{~A}$ & A & "Eksiklik" & $\begin{array}{l}\text { "Aileden birinin bir eksiği vardır; Aileden biri } \\
\text { bir şeyi elde etmek ister." }\end{array}$ \\
\hline 9 & B & "Aracılık, Geçiş Anı" & $\begin{array}{l}\text { "Kötülüğün ya da eksikliğin haberi yayılır, } \\
\text { bir dilek ya da bir buyrukla kahramana } \\
\text { başvurulur, kahraman gönderilir ya da gider." }\end{array}$ \\
\hline 10 & C & $\begin{array}{l}\text { "Karşıt Eylemin } \\
\text { Başlangıcı" }\end{array}$ & $\begin{array}{l}\text { "Arayıcı-kahraman eyleme geçmeyi kabul } \\
\text { eder ya da eyleme geçmeye karar verir." }\end{array}$ \\
\hline 11 & $\uparrow$ & "Gidiş" & "Kahraman evinden ayrılır." \\
\hline 12 & $\mathrm{D}$ & "Bağışçının İlk İşlevi" & $\begin{array}{l}\text { "Kahraman büyülü bir nesneyi ya da } \\
\text { yardımcıyı edinmesini sağlayan bir sınama, } \\
\text { bir sorgulama, bir saldırı, vb. ile karşılaşır." }\end{array}$ \\
\hline 13 & E & $\begin{array}{l}\text { "Kahramanın } \\
\text { Tepkisi" }\end{array}$ & $\begin{array}{l}\text { "Kahraman ilerde kendisine bağışta } \\
\text { bulunacak kişinin eylemlerine tepki gösterir." }\end{array}$ \\
\hline 14 & $\mathrm{~F}$ & $\begin{array}{l}\text { "Büyülü Nesnenin } \\
\text { Alınması" }\end{array}$ & "Büyülü nesne kahramana verilir." \\
\hline 15 & G & $\begin{array}{l}\text { "Bir Kılavuz } \\
\text { Eşliğinde Yolculuk" }\end{array}$ & $\begin{array}{l}\text { "Kahraman, aradığı nesnenin bulunduğu } \\
\text { yere ulaštırılır, kendisine kılavuzluk edilir ya } \\
\text { da götürülür." }\end{array}$ \\
\hline 16 & $\mathrm{H}$ & "Çatışma" & $\begin{array}{l}\text { "Kahraman ve saldırgan, bir çatışmada karşı } \\
\text { karşıya gelir." }\end{array}$ \\
\hline 17 & I & “Özel İşaret” & "Kahraman özel bir işaret edinir." \\
\hline 18 & J & "Zafer" & "Saldırgan yenik düşer." \\
\hline
\end{tabular}




\begin{tabular}{|c|c|c|c|}
\hline 19 & $\mathrm{~K}$ & "Giderme" & $\begin{array}{l}\text { "Başlangıçtaki kötülük giderilir ya da eksiklik } \\
\text { karşılanır." }\end{array}$ \\
\hline 20 & $\downarrow$ & "Geri Dönüş" & "Kahraman geri döner." \\
\hline 21 & $\mathrm{Pr}$ & "İzleme" & "Kahraman izlenir." \\
\hline 22 & Rs & "Yardım" & "Kahramanın yardımına koşulur." \\
\hline 23 & O & $\begin{array}{l}\text { "Kimliğini Gizleyerek } \\
\text { Gelme" }\end{array}$ & $\begin{array}{l}\text { "Kahraman kimliğini gizleyerek kendi } \\
\text { ülkesine ya da bir başka ülkeye varır." }\end{array}$ \\
\hline 24 & $\mathrm{~L}$ & "Asılsız Savlar" & $\begin{array}{l}\text { "Düzmece bir kahraman asılsız savlar ileri } \\
\text { sürer." }\end{array}$ \\
\hline 25 & M & "Güç" & "Kahramana güç bir iş önerilir." \\
\hline 26 & $\mathrm{~N}$ & $\begin{array}{l}\text { "Güç İşi Yerine } \\
\text { Getirme" }\end{array}$ & "Güç iş yerine getirilir." \\
\hline 27 & Q & "Tanıma” & "Kahraman tanınır." \\
\hline 28 & Ex & "Ortaya Çıkarma” & $\begin{array}{l}\text { "Düzmece kahramanın, saldırganın ya da } \\
\text { kötünün gerçek kimliği ortaya çıkar." }\end{array}$ \\
\hline 29 & $\mathrm{~T}$ & "Biçim Değiştirme" & “Kahraman yeni bir görünüm kazanır." \\
\hline 30 & $U$ & "Cezalandırma" & $\begin{array}{l}\text { "Düzmece kahraman ya da saldırgan } \\
\text { cezalandırılır." }\end{array}$ \\
\hline 31 & $\mathrm{~W}^{\circ} \mathrm{O}$ & "Evlenme" & "Kahraman evlenir ve tahta çıkar." \\
\hline
\end{tabular}

Propp belirlediği 31 işlevin dört ilkeye göre çalıştığını iddia etmektedir (Knyf, 2009, s. 18).

- Işslevler kararlı, sabit ögelerdir.

- İşlevler sınırlıdır.

- İşlevlerin sırası aynıdır.

- Tüm peri masalları aynı yapıyı paylaşır.

Propp'un tespit ettiği bu dört ilkeden "işlevlerin sırası aynıdır" ilkesi bazı durumlarda sorunlar yaratmaktadır. Bir kahraman herhangi bir yasak koymadan ihlal eyleminin gerçekleşmesi mümkün değildir (Knyf, 2009, s. 18). Daha açık bir ifadeyle Propp yöntemindeki 4 önemli bulguyu şu şekilde detaylandırmaktadır (Propp, 2001, ss. 40-43):

- Masalda bulunan karakterler ve işlevler nasıl ve hangi şartlarda ortaya çıkarsa çıksın, masalın değişmez sürekli ögeleri kişilerin işlevleridir ve bu sabit işlevler masalın iskeletini oluşturmaktadır.

- Olağanüstü masallarda karşılaşılan işlevlerin sayısı sınırlıdır. Propp'a göre bu işlevler belirlendikten sonra işlevlerin masal içerisinde ne tür bir kümelenme ve düzen içerisinde bulunduğu incelenmelidir. Örneğin bir olaya tanık olanların açıklamalarından yola çıkarak tanıklar olayın gidişatında değişsiklik yaparsa 
anlatıların önemi ortadan kalmaktadır. Nasıl ki olayların düzeninin kendi yasaları varsa yazınsal anlatıların da kendilerine yönelik yasaları bulunmaktadır. Bir hırsızlık işlevinin gerçekleşmesi için kapının kırılmasına ihtiyaç duyulmaktadır.

- Işslevlerin dizilişi her zaman aynıdır. Propp'a göre belirlenen bütün işlevler masallarda yer almayabilir. Ancak bu durum işlevlerin belirli bir düzene göre sıralanışını yani biçimini değişikliğe uğratmaz. Eksik olan işlevler diğer işlevlerin düzenini bozmaz. Örneğin her yerde karşılaştığımız ilk işlevi A ile eğer varsa ardından gelen işlevi B ile belirtirsek masallarda belirtilen tüm işlevleri tek anlatı yapısına göre düzenleriz. Böylece işlevlerin sıraları bozulmaz, birbirlerini dışlamaz ve birbirleriyle çelişmezler.

- Olağanüstü masallar yapıları açısından incelendiğinde tek tipe bağlanmaktadır. Araştırmacılar bu sınıflandırmanın yapılabilmesi için tüm masalların incelenmesi gerektiğini belirtmektedir. Propp, bu detaylı bütünce incelemesine gerek olmadığını, masalları kişilerin işlevlerinden yola çıkarak incelediğimizde yeni bir işlevle karşılaşılmadığı durumda incelemenin bitirilmesi gerektiğini öne sürmektedir. Ayrıca çeşitli konulara yönelik 100 masalı incelediklerinde fazlasıyla yeterli bir bütüncenin oluştuğunu belirtmektedir.

Olağanüstü masallarda karakterlerin olay örgüsü boyunca benzer özelliklere (görünüş, yaş, cinsiyet, medeni hâl, diğer statik ve niteliksel özellikler de dâhil) sahip olduğunu söylemek mümkündür. Sahip olunan sabit değişkenler işlevlerin belirlenmesinde önemli rol oynamaktadır. Karakterlerin işlevleri sabitliği temsil etmektedir. Ancak olağanüstü masalların içerisinde bunun dışında her şey değişiklik gösterebilmektedir. Örneğin yakışıklı bir prens güzel bir prensesi kurtarmak için bir ejderha ile savaşmak zorunda kalabilir ya da güçlü bir asker sevdiği kadını kurtarmak için düşmanlarıyla savaşabilir. İçerik değişse bile biçim aynı kalmaktadır. Yani burada kurtarma ve arayış işlevi sabit değişkenlerdir ancak kurtarılacak olan kişiler, karşılaşılan engeller ve düşmanlar değişkenlik göstermektedir (Yen, 1973, s. 178). Propp'a göre kahramanların işlevleri gerçekleştirme biçimleri birbirlerini etkilemekte, aynı biçimler de değişik işlevlere uygulanmaktadır. Bir biçim yeni bir anlam kazanarak ya da eski anlamını da koruyarak yer değiştirebilmektedir (Propp, 2001, s. 94).

Propp'un incelediği masallarda her şey genellikle bir kötülükle başlar; kötülük belli bir ailede, belli bir çevrede bir eksiklik yaratır (sözgelimi küçük bir kızın kaçırılması), bir kahraman (bu durumda arayıcı kahraman) bu eksikliği gidermekle, dolayısıyla kötülüğü. ortadan kaldırmakla görevlendirilir, ona eyleminde (yapacağı güç ve zor işte) birileri yardım ederken, birileri de karşı çıkar. Kahraman, birçok sınamadan geçerek (bu arada bir iki kez de başarısızlığa uğrayarak) eksikliği gidermeye çalışır ve sonunda görevini başarınca ödüllendirilir (arayıcı kahramanın bulunmadığı masallarda anlatı kurban kahramanın çevresinde gelişir). Bu genel anlatı süreci içinde 
yer alan işlevler, yukarıda da belirttiğimiz gibi aynı sıralama içinde birbirini izlerken, yine Propp'a göre yedi kişinin (anlatı kişisinin) eylem alanı içinde dağılım gösterir (Propp, 2001, ss. 11-12):

\section{Tablo 2: Anlatı Kişisinin Eylem Alanı}

1. "Saldırganın Eylem Alanı"

2. "Bağışçının (Sağlayıcının) Eylem Alanı"

3. "Yardımcının Eylem Alanı"

4. "Prensesin (Aranan Kişinin) ve Babasının Eylem Alanı"

5. "Gönderenin (Görevlendirenin) Eylem Alanı"

6. "Kahramanın Eylem Alanı"

7. "Düzmece Kahramanın Eylem Alanı"

Propp belirlediği 31 işlevin gerçekleştirilmesi için yukarıda bahsi geçen 7 eylem alanına ihtiyaç duyulduğunu belirtmektedir. Bir masal incelemesi yapılırken önemli olan unsur, karakterlerin ne yaptıklarını bilmektir. Hangi karakter, hangi eylemi nası ve neden yapar; bunlar sorulması gereken sonraki sorulardır. Karakterlerin işlevleri masaIın ana bölümlerini göstermektedir. Bu nedenle öncelikle ayırt etmemiz gerekenler de bu işlevlerdir (Propp, 2001, ss. 38-39).

\section{Modele Yönelik Eleştiriler}

Antropoloji ve dilbilimi alanında yöntem olarak yapısal çözümlemeyi benimseyenler biçimcilikle suçlanmaktadır. Bu suçlamalarda bulunanlar, yapısalcılığın aslında biçimciliğe çok şey borçlu olan ancak somuta karşı benimsediği tavırla biçimcilikten ayrılan bağımsız bir doktrin olarak var olduğunu unutmaktadırlar. Yapısalcılık biçimselliğin aksine somutu, soyutun karşısına koymayı ve soyuta daha fazla önem vermeyi reddetmektedir. Biçimci geleneğe bağlı olan Vladimir Propp, Morphology of the Folktale (Masalın Morfolojisi) eserinin sahibi olmakla birlikte 1915'ten 1930'a kadar geliştiği kısa süre boyunca Rus biçimci okulunun ana temsilcilerinden biri olarak bilinmektedir. 1928'de kendisini bir krizin içerisinde bulan Rus biçimcilik okulu Sovyetler Birliği'nde kınanarak dış dünyayla teması koparılmıştır. Bu yüzden Propp biçimcilikten ve biçim bilimsel çözümlemeden vazgeçmek zorunda kalmış olup sonraki dönemlerde sözlü edebiyatın mitler, ritüeller ve kurumlarla ilişkileri üzerine tarihsel ve karşılaştırmalı araştırmalarına kendini adamıştır (Levi Strauss, 1983, ss. 115-116). 
Yapısalcılık ve biçimbilimi ayrımında Propp ve Levi-Strauss ikilemine değinmek gerekmektedir. Levi-Strauss Structural Anthropology (2) kitabında yer alan "Structure and Form: Reflections on a Work by Vladimir Propp" isimli bölümde Propp'un Masal'ın Morfolojisi eserini değerlendirmiştir. Bu bölümde Levi-Strauss Propp'un kitabına yönelik detaylı bir inceleme yaparak yönteminde bulduğu eksikleri yapıcı bir dille eleştirmiştir.

Levi Strauss, Propp'u geliştirmiş olduğu yönteminde bazı yanılgılara sahip olduğu, çözümlemeyi yeterince geliştirmediği ve sadece biçime yönelip içeriği göz ardı ettiği gerekçesiyle eleştirmiştir (Yücel, 2005, s. 123). Buna göre Levi-Strauss biçim ve yapısalcılık ayrımı yapanlara yönelik görüşlerini şu şekilde aktarmaktadır (Levi Strauss, 1983, s. 131):

Biçimcilik ile yapısalcılık arasındaki farkı özetlediği için bu noktayı vurgulamak istiyorum. Biçimcilik için iki alan kesinlikle ayrı olmalıdır çünkü biçim tek başına anlaşılabilirdir ve içerik yalnızca herhangi bir önemli değerden yoksun kalan bir kalıntıdır. Yapısalcılık için bu karşıtlık yoktur; yapısalcılık birini soyut, diğerini somut olarak ele almaz. Biçim ve içerik aynı niteliktedir ve aynı tür analize uygundur. İçerik, gerçekliğini yapısından alır ve biçim denen şey, bu içeriği oluşturan yerel yapıları düzenlemenin bir yoludur.

A. J. Greimas ise Propp'un 31 işlevinden bazılarının birbirini tekrarladığını söyleyerek işlevlerin daha az sayıya indirgenebileceğini belirtmiştir. Ancak Propp'un bu yöntemin ilk uygulayıcısı olması ve kendinden sonra gelen araştırmacılara öncü olması onu ve geliştirdiği yöntemi önemli kılmaktadır (Yücel, 2005, s. 123).

Greimas'ın görüşlerinden yola çıkarak Propp'un bütün masalları sadece 31 işlev ile açıklamaya çalışması okuyucularda farklı görüşlerin oluşmasına zemin hazırlamıştır. Örneğin Levi-Strauss; “'ihlal etme'yi ‘yasaklama'nın tersi, yasaklamayı ise 'buyurma'nın olumsuz bir dönüşümü olarak kabul etmek mümkündür" demektedir. Bu nedenle Propp'un belirlemiş olduğu 31 işlev hem fazla büyük hem de fazla küçüktür. Tüm masallarda bulunabilecek işlevleri düşündüğümüzde sayı oldukça az ancak yüzeysel bir bakışla bile belirlenen bazı eylemlerin birbirinin yerine kullanılacağını gördüğümüzde sayı oldukça fazladır (Todorov, 2014, s. 92).

Propp'un çözümlemesinde gözden kaçan bir diğer husus Propp'un peri masalları ile ilgili romanları değil yalnızca kısa olma özelliği gösteren kısa öyküleri seçmesinin sonucunda ortaya çıkmaktadır. Çünkü anlatı kurgusunun uzunluğu biçimsel ve yapısal olarak karmaşıkı̆̆ı içerisinde barındırmaktadır. Propp'un değinmekten kaçındığı romanlarda ve filmlerde kahramanın bağışçılar ve yardımcılarla etkileşimi tek bir örnekle sınırlı olmamaktadır. Masalın anlatı yapısını incelemek için metindeki içeriklerle filmin tutarlılıklarını tespit etmek gerekmektedir. Filmlerin masal olarak sınıflandırı- 
labilmesi için anlatının belirlenen işlevleri içermesi gerekmektedir (Knyf, 2009, s. 19). Biçimciler görüntünün sadece gerçeğin bir yansıması olduğu, gerçeğin benzeri olmadığını bilmektedir. Bu bağlamda nesnel gerçeklik sinemanın ilgilendiği bir konudur (Lotman, 2012, s. 7).

\section{Being There Filminin Propp'un Biçim Bilimsel Çözümleme Yöntemiyle Analizi}

\section{Çalışmanın Amacı}

Propp geliştirmiş olduğu yöntemle yapıtlarda olaylar ve kişiler değişiklik gösterse de işlevlerin ve eylem alanlarının sabit kaldığını ve tekdüze bir özellik gösterdiğini belirtmektedir. Yöntemini olağanüstü ve kısa yapıdaki masallarla sınırlı tutarak yazınsal bir alanda test etmiştir. Propp'un yöntemini oluşturduğu dönemlerden sonra görsel ve işitsel iletişim alanında büyük gelişmeler meydana gelmiştir. Yaşanan gelişmeler sonucunda bireylerin beklentileri değişmiştir. Yapımcılar bu beklentiler doğrultusunda filmi izlerken sonunun tahmin edilemediği ve merak uyandıran yaratıcı içerikler üretmeye başlamıştır. Bu durum olay örgüsünün değişmesine ve sonda verilen sahnelerin bazen en başta seyirciye sunulmasına sebep olmuştur.

Zamanla Propp'un analiz yöntemi de masallarla sınırlı kalmayıp roman, hikâye, dizi, film, tiyatro ve reklam gibi farklı alanlarda da kullanılmıştır. Bu alanlardan birisi olan sinemada son dönemlerde roman, hikâye, masal, destan gibi yazınsal yapıtlardan uyarlanan filmlerin varlığı artış göstermektedir. Ulusal ve uluslararası alanyazın incelendiğinde Propp'un yönteminin yoğun olarak olağanüstü ve fantastik türdeki filmlerin analizi için kullanıldığı ve yöntemle uyumlu bir çözümleme yapıldığı görülmektedir. Bu bağlamda bir romandan uyarlanmış olan ve içerisinde zaman zaman masalsı motifler barındıran Being There filminin Propp'un yöntemiyle analiz edilip edilemeyeceği çalışmanın amacını oluşturmaktadır. Her iki durumun da gerekçeleri verilerin analizi aşamasında açıklanacak olup yapılan çalışma ile sinema filmlerinin analizinde araştırmacılara kolaylık sağlanması amaçlanmaktadır.

\section{Çalışmanın Yöntemi}

Çalışmada yöntem olarak Vladimir Propp tarafından geliştirilen biçimbilimsel çözümleme yöntemi kullanılmıştır. Bu yöntemde yazınsal bir yapıtın biçimbilimsel çözümlemesinin yapılması için oluşturulan 31 işlev ve 7 eylem alanı bulunmaktadır. Propp'un yönteminde belirlediği 31 işlev; "Uzaklaşma, yasaklama, yasağı çiğneme, soruşturma, bilgi toplama, aldatma, suça katılma, kötülük, eksiklik, aracılık (geçiş anı), karşıt eylemin başlangıcı, gidiş, bağışçının ilk işlevi, kahramanın tepkisi, büyülü nesnenin 
alınması, bir kılavuz eşliğinde yolculuk, çatışma, özel işaret, zafer, giderme, geri dönüş, izleme, yardım, kimliğini gizleyerek gelme, asılsız savlar, güç, güç işi yerine getirme, tanıma, ortaya çıkarma, biçim değiştirme, cezalandırma, evlenme" olarak sınıflandırılırken; 7 eylem alanı ise "saldırganın eylem alanı, bağışçının (sağlayıcının) eylem alanı, yardımcının eylem alanı, prensesin (aranan kişinin) ve babasının eylem alanı, gönderenin (görevlendirenin) eylem alanı, kahramanın eylem alanı, düzmece kahramanın eylem alanı" şeklinde kategorize edilmiştir. Propp yöntemini oluşturan işlev ve eylem alanlarını olağanüstü masalların çözümlemesini yaparak oluşturmuştur. Bu bağlamda yazınsal anlatıdan farklı olarak sinema da Propp'un işlev ve eylemlerinin karşılık bulup bulmayacağı sorgulanmıştır. Yapılan çalışma da Being There filmi Propp'un yöntemindeki işlevler ve eylem alanları açısından çözümlenmiştir.

\section{Çalışmanın Evreni ve Örneklemi}

Ulusal ve uluslararası alanyazında Propp'un biçimbilimsel çözümleme yöntemiyle yapılan çalışmalar incelendiğinde yoğun olarak fantastik kurguların ve ülkelerin kendilerine özgü masallarının çözümlemesinin yapıldığı görülmektedir. Örneğin ulusal alanyazında; Bars (2014) "Vladimir Propp'un Yapısal Çözümleme Yöntemi Çerçevesinde Battal Gazi Destanı Filminin İncelenmesi", Özçalışkan (1996) "Vladimir Propp'un Biçim Bilimsel Yaklaşımı Çerçevesinde Bir Keloğlan Masalının İncelenmesi", Uğur \& Günaydın (2019) "Vladimir Propp'un Yapısal Çözümleme Yöntemi Çerçevesinde "Tadeo Jones 2: Kral Midas'ın Sırrı" Filmi İncelemesi", Abalı (2013) "Yapısal Folklor Kuramı Bağlamında Bir Masal İncelemesi Örneği" çalışmaları Propp'un biçim bilimsel çözümleme yöntemiyle analiz edilmiştir. Masal motiflerini ve unsurlarını içerisinde barındırmaları bu çalışmaların ortak özelliklerini oluşturmaktadır. Yapılacak olan çalışmada evren sinema filmi bulunan yazınsal bir yapıtla sınırlandırılmış olup örneklem olarak Being There filmi seçilmiştir.

\section{Çalışmanın Sınırlılıkları ve Önemi}

Çalışma Being There sinema filmiyle sınırlandırılmıştır. Ayrıca alanyazındaki çalışmalar incelendiğinde genellikle masal ve destan özelliği gösteren yapıtların çözümlemesinin yapıldığı saptanmıştır. Bu bağlamda farklı bir bakış açısı sunmak amacıyla, yapılan çalışmada Propp'un uzun ve karmaşık olay örgüsünden dolayı çözümleme yapmadığı roman türü tercih edilmiştir. Bu çalışmada elde edilen veriler, edebî bir yapıt olan romanların biçimbilimsel olarak çözümlemesinin yapılmasında örnek olması hususunda önem arz etmektedir. Öte yandan yazınsal bir çözümleme yöntemi olan, içerisinde 31 işlev ve 7 eylem alanı bulunan bu yöntemin sinema alanında kendisine karşılık bulması sonucunda sonradan yapılacak olan çalışmalara katkı sağlayacağı düşünülmektedir. 


\section{Araştırma Soruları}

Çalışmanın ‘bulgular' kısmında bu üç araştırma sorusu cevaplanmaktadır:

1. Bir yazınsal metin incelemesi için oluşturulan yöntem farklı disiplinlerde uygulanabilir mi?

2. Sinema filmlerinde senaryo yazımının çerçevesini çizmek için bu yöntem kullanılabilir mi?

3. Belirlenen işlevler yapıtların yaratıcılığını olumsuz etkiler mi?

\section{Being There Filminin Propp'un Biçim Bilimsel Çözümleme Yöntemi ile Çözümlenmesi}
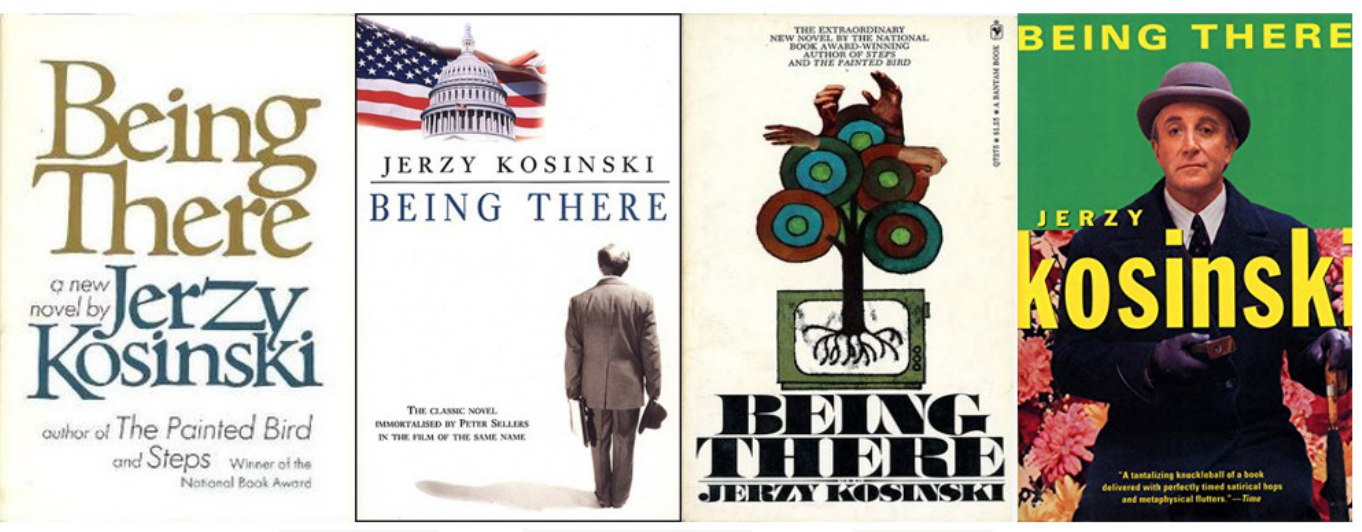

Fotoğraf 1: Being There Kitap Kapakları

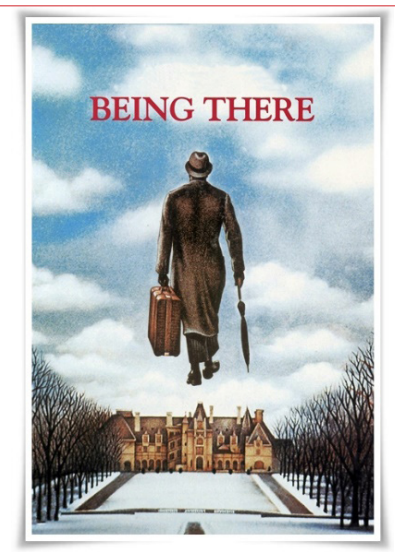

Fotoğraf 2: Being There Film Afişi (1979) 


\section{Being There Filminin Konusu}

19 Aralık 1979 yılında sinemalarda yerini alan Being There filmi Türkiye'de Merhaba Dünya ismiyle 1984 yılında vizyona girmiştir. Yönetmenliğini Hal Ashby'nin yaptığı filmin senaryosu Jerzy Kosinski ve Robert C. Jones'a aittir.

Being There filminin ana karakteri Chance (Peter Sellers)'dir. Chance doğduğu günden itibaren Washington'da zengin ve yaşlı bir adamın evinde bahçıvanlık yapmaktadır. Aynı zamanda Chance bu malikaneden dışarı hiç çıkmayarak tüm hayatını malikanenin bahçesinde geçiren ve dış dünya ile hiçbir bağlantısı bulunmayan orta yaşlı saf bir karakterdir. Chance'in dış dünya hakkında bildiği her şey malikanede bulunan televizyonda gördükleri ve izlediklerinden ibarettir. Bir gün yaşlı adamın ölmesi sonucu evden ayrılması gereken Chance dış dünyanın televizyondaki kurgulanmış dünyadan farklı olduğunu deneyimleyerek öğrenecektir.

\section{Verilerin Analizi}

\section{"O-Başlangıç durumu."}

Filmin olay örgüsü ana karakter olan Chauncey (Chance) Gardiner'ın güne uyanması ve günlük rutin işlerini televizyon izleyerek gerçekleştirmesiyle başlar.

\section{"7-Aileden biri evden uzaklaşır."}

Being There filminde birden fazla evden uzaklaşma sahnesi bulunmaktadır. Bunlardan ilki Chance'in yıllarca yanında çalıştığı ve yaşlı adam diye bahsettiği kişinin ölmesidir. İkincisi ise Chance ile aynı evde çalışan ve evin işleriyle ilgilenen Louise'in yaşlı adam öldükten sonra evden ayrılmasıdır.

\section{"2-Kahraman bir yasakla karşılaşır."}

Avukatlık bürosundan gelen Thomas yaşlı adamla bir akrabalığının bulunmadığını belirterek Chance'in malikaneden ayrılmasını ister.

\section{"3-Yasak çiğnenir"}

Chance, yaşlı adamla akrabalık bağı bulunmadığı hâlde Thomas gelene kadar malikanede yaşayarak yasağı çiğner.

\section{"4-Saldırgan bilgi edinmeye çalışır."}

Filmde kahraman hakkında bilgi edinmeye yönelik çok sayıda sahne bulunmaktadır. Ancak bunların hepsi saldırganın bilgi toplama eylemiyle ilgili değildir. Örneğin; 
$\triangleright$ Avukatlık bürosu memurlarının malikaneye gelerek Chance hakkında bilgi edinmeye çalışması, Chance'in geçirdiği ufak bir kazadan sonra sağlığıyla ilgilenen Dr. Robert'ın Chance hakkında bilgi edinmeye çalışması ve kazadan sonra evlerinde kaldığı Benjamin ve Eve çiftinin Chance'in hayatını sorgulaması. Bu bilgi edinme süreçleri kahramana yardımcı olmak için yapılan eylemleri kapsamaktadır.

$\triangleright$ Bunun yanı sıra ilerleyen sahnelerde potansiyel saldırgan diyebileceğimiz dönemin ABD Başkanı Bobby, Chance hakkında bilgi edinmeye çalışır.

\section{“5- Saldırgan kurbanıyla ilgili bilgi toplar."}

Chance'in varlığından rahatsız olan dönemin ABD Başkanı Bobby'nin talimatıyla adamları Chance hakkında bilgi toplamaya başlar.

Chance'in ününü duyan televizyon kanalı sahipleri onun kimliği hakkında bilgi toplar.

\section{"6-Saldırgan, kurbanını ya da servetini ele geçirmek için, onu aldatmayı dener."}

Başkan Bobby Benjamin ile yapacağı toplantıya Chance'in katılmasından rahatsızlık duyar ancak ona iyi davranır ve onun toplantıda söylediği sözleri meclis konuşmasında kullanır. Ancak toplantı çıkışında adamlarına Chance'i araştırmalarını emreder.

\section{“7- Kurban aldanır ve böylece istemeyerek düşmanına yardım etmiş olur."}

Filmde 3 ayrı sahne bu maddeye örnek oluşturmaktadır;

$\triangleright$ Chance kendisine gelen davetleri kabul eder ve programlara katılır. Chance kuliste program için hazırlanırken Başkan Bobby'nin adamları tarafından kimliğinin belirlenmesi amacıyla Chance'e tuzak kurulur.

$\triangleright$ Yaşlı adamın malikanesinde ev işleriyle ilgilenen Louise, Chance'i televizyonda görür ve onu tanır. Yanında bulunan kişilere Chance'in göründüğü gibi zeki birisi olmadığını hatta zekasında bir problem olduğunu anlatır.

$\triangleright$ Avukatlık Bürosu memuru Thomas'da Chance'i televizyonda tanır. $\bigcirc$ da Chance'in televizyonda gösterildiği gibi birisi olmadığını bilir. İlgili biriyle görüşmek için harekete geçer.

\section{"8-Saldırgan aileden birine zarar verir."}

Filmde bu işleve yönelik bir sahne bulunmamaktadır.

"8A- Aileden birinin bir eksiği vardır; aileden biri bir şeyi elde etmek ister." 
Chance malikaneden ayrıldıktan sonra kendisine evini açan Eve ve Benjamin çiftini ailesi gibi görmüştür. Benjamin'in ölümcül bir hastalığı bulunmaktadır. Onun için sağlık bir eksikliktir. İyileşmesi için evin içinde bir hastane kurulmuştur ve herkes onun iyi olması için çalışmaktadır.

Bunun yanı sıra Chance sosyal zekaya sahip bir birey değildir. Yaşantısını bir malikaneden hiç dışarı çıkmadan sürdürmüştür. Bu yüzden onu güvende hissettiren televizyon kumandasına bir bağlılık hissetmektedir. Filmin ilk sahnelerinde Chance televizyon kumandasını kaybetmiştir. Bu Chance'de bir eksiklik hissi yaratmaktadır.

\section{“9-Kötülüğün ya da eksikliğin haberi yayılır, bir dilek ya da bir buyrukla kahramana başvurulur, kahraman gönderilir ya da gider."}

Eve, Chance'e Benjamin'in hasta olduğunu söyleyerek Chance'in misafirleri olarak kalmasını istediklerini söyler.

\section{"10-Arayıcı-kahraman eyleme geçmeyi kabul eder ya da eyleme geçmeye karar verir."}

Chance evde misafir olarak kalmayı kabul eder.

Benjamin'in teklifi üzerine Başkan Bobby ile toplantıya katılmaya karar verir.

\section{"11-Kahraman evinden ayrılır."}

Chance yaşlı adam öldükten sonra evden ayrılır.

Chance televizyon programlarına katılmak için Benjamin ve Eve'in evinden ayrılır.

Chance senatörün davetine katılmak için evden ayrılır.

\section{"12- Kahraman büyülü bir nesneyi ya da yardımcıyı edinmesini sağlayan} bir sınama, bir sorgulama, bir saldırı, vb. ile karşılaşır."

Chance yaşlı adamın evinden ayrıldıktan sonra küçük bir kaza geçirir. Eve'in şoförü Chance'e arabayla çarpar. Eve, Chance'in tedavisiyle ilgilenmek ister ve araba yolculuğu boyunca ona sorular sorar.

\section{"13- Kahraman ilerde kendisine bağışta bulunacak kişinin eylemlerine tepki gösterir."}

Chance kendisine arabayla çarpan Eve'in teklifini kabul eder ve tedavi sürecini geçirmek için Eve'in evine gider.

Senatör Benjamin'e davetine katılması için bir teklifte bulunur. Ancak Benjamin hasta olduğu için kendisinin yerine Chance'in katılmasını ister. 


\section{"14-Büyülü nesne kahramana verilir."}

Filmde büyülü nesne diyeceğimiz tek obje televizyon kumandasıdır. Çünkü Chance için televizyonun yaratmış olduğu kurgusal dünyadaki savunma mekanizması uzaktan kumandadır. Chance uzaktan kumanda ile kanallar arası geçiş yaptığında kontrolün kendisinde olduğunu bilerek rahatlamaktadır. Kendisini rahatsız eden, hoşlanmadığı içerikleri uzaktan kumanda ile değiştirerek bunlardan kurtulduğunu düşünmektedir. Bu bağlamda yaşlı adamın evinde yaşarken sahip olduğu uzaktan kumandayı evden ayrılmak zorunda kalınca bir sokakta kaybeder.

\section{"15-Kahraman, aradığı nesnenin bulunduğu yere ulaştırılır, kendisine kılavuzluk edilir ya da götürülür."}

Yaşlı adamın ölümünden sonra evden ayrılmak zorunda kalan Chance araba çarptığı esnada kumandasını kaybetmiştir. Eve'in evlerinde televizyon olduğunu belirtmesi üzerine Chance yeni bir kumandaya sahip olacağını düşünerek Eve'in evine gitmeyi kabul eder.

\section{“16-Kahraman ve saldırgan, bir çatışmada karşı karşıya gelir."}

Benjamin ve Başkan Bobby'nin toplantısına katılan Chance sorularla karşı karşıya kalır. Başkan Bobby daha önce hiç görmediği ve tanımadığı Chance'i önemli biri zannederek onunla ilgili bilgiler toplamak için sorular sorar.

\section{"17-Kahraman özel bir işaret edinir."}

Chance, kaza sırasında ayağından yaralanır ancak hayatta kalmayı başarır.

\section{"18- Saldırgan yenik düşer."}

Başkan Bobby adamlarına Chance hakkında bilgi edinmek için direktif verir ancak onun hakkında hiçbir bilgiye ulaşamaz. Başkanın adamları Chance ile ilgili yaşadığı ve doğduğu yer, ses analizi, DNA örneği, hastane raporları gibi konularda araştırmalar yapar ancak hiçbir sonuca ulaşamaz. Çünkü Chance doğduğundan beri yaşlı adamın evindedir ve bir kimliği yoktur.

\section{“19-Başlangıçtaki kötülük giderilir ya da eksiklik karşılanır."}

Chance eksikliğini yaşadığı televizyon ve uzaktan kumandaya Rand çiftinin evinde kavuşmuştur.

Chance yaşlı adam öldükten sonra ne yapacağını bilemez hâlde sokakta kalmıştır. Ancak Eve ile tanışması sonucunda yeniden bir eve sahip olmuştur. 


\section{"20-Kahraman geri döner."}

Filmin son sahnesinde Benjamin'in ölümüyle birlikte yine evsiz kalacağını düşünen Chance cenaze töreninde sessizce kalabalığın içinden ayrılarak bilinmeze gitmeye başlar.

\section{"21-Kahraman izlenir."}

Filmde kahraman birçok sahnede izlenmektedir. İzleme davranışlarını gerçekleştiren kişiler;

$\triangleright$ Avukatlık bürosu memuru Thomas ve Selly,

$\triangleright$ Malikanede ev işleriyle ilgilenen Louise,

$\triangleright$ Dr. Robert,

$\triangleright$ ABD Başkanı Bobby ve Adamları,

$\triangleright$ Medya Mensupları'dır.

\section{"22-Kahramanın yardımına koşulur."}

Selly, Chance'e yardımcı olmak için teklifte bulunur.

Şoförünün Chance'e arabayla çarpması sonucunda Eve, Chance'in sağlığıyla ilgilenmeyi teklif eder.

Bir yanlış anlaşılma sonrası Chance'in varlıklı bir iş insanı olduğunu ancak iflas ettiğini zanneden Benjamin ona yeni fikri olan "Iş̧ Adamlarına Yardım Fonu Başkanlığı" teklifinde bulunur.

Chance'in göründüğü gibi birisi olmadığını anlayan Dr. Robert bu gerçeğin farkında olan Thomas ile yaptığı görüşme sonrasında ona bu bildiklerini kimseye anlatmamasını söyleyerek Chance'i korur.

\section{"23-Kahraman kimliğini gizleyerek kendi ülkesine ya da bir başka ülkeye varır."}

Film yanlış anlaşılmalar üzerine kurgulanmıştır. Kahramanımızın ismi Chauncey (Chance)'dir. Mesleği ise bahçıvanlıktır. Ancak kendisini tanıtması gerektiğinde Chauncey (Chance) Gardiner olarak tanıttığı için insanlar Gardiner'ı Chance'in soy ismi sanmaktadır. Bu soy isim saygın bir aileye ait olduğu için Chance zengin bir iş insanı olarak düşünülür. Bu yüzden film boyunca kimliği genelde gizli bir şekilde aktarılmaktadır. 


\section{"24-Düzmece bir kahraman asılsız savlar ileri sürer."}

Senatörün verdiği davete katılan kişiler Chance hakkında asılsız savlar ortaya atar. (Örneğin; 8 dili çok akıcı konuşması, tıp ve hukuk diplomasına sahip olduğu vb.)

Başkan Bobby ve adamları hakkında bilgiye ulaşamadıkları Chance'in FBı ajanı olduğunu düşünür.

\section{"25-Kahramana güç bir iş önerilir."}

Chance yaşlı adamın evinden ayrıldıktan sonra sokaklarda gezerken genç bir siyahi grupla karşılaşır. Bu grup Chance'i korkutarak Rafiel'e bir mesaj iletmesini ister.

Benjamin hastalığından dolayı senatörün davetine katılamayacaktır. Bunun için Chance'ten bu davete katılması istenir.

\section{"26-Güç iş yerine getirilir."}

Chance Rafiel'in mesajını Benjamin'e anlatır.

Chance ve Eve birlikte senatörün davetine katılır.

\section{"27-Kahraman tanınır."}

Chance Başkan Bobby'nin konuşmasında kendisinden bahsetmesi üzerine merak edilen birisi olur. Bu yüzden medya kanalları Chance'e ulaşmak için Benjamin'in evini arar. Chance, aramaları yanıtlayarak bir televizyon programına katılmaya karar verir. Bunun sonucunda herkes onu tanır. Bir diğer tanınma sahnesi ise senatörün davetine katılım sağlamasıyla gerçekleşmektedir.

\section{"28-Düzmece kahramanın, saldırganın ya da kötünün gerçek kimliği ortaya çıkar."}

Filmde bu işleve yönelik bir sahne bulunmamaktadır.

\section{"29- Kahraman yeni bir görünüm kazanır."}

Konuşmaları ve doğallığıyla halkın gönlünü kazanan Chance bir grup insan tarafından sonraki seçimler için başkan adayı olarak düşünülür.

\section{"30-Düzmece kahraman ya da saldırgan cezalandırılır."}

Cezalandırma tam anlamıla gerçekleştirilmez ancak Thomas, Chance hakkında bildiği gerçekleri açıkladığında bir kazanç elde edeceğini düşünerek Dr. Robert ile buluşur. Ancak Dr. Robert bildiklerini kimseye anlatmamasını söyleyerek gözdağı verir. 


\section{"31- Kahraman evlenir ve tahta çıkar."}

Filmde bu işleve yönelik bir sahne bulunmamaktadır.

Ölümcül hastalığı bulunan Benjamin öldükten sonra eşi Eve'in filmin kahramanı Chance ile mutlu olmasını ister. Benjamin'in cenaze töreninin temsil edildiği sahnede Chance Benjamin'e karşı son görevini tamamlar. Ancak biz bu işlevin gerçekleşip gerçekleşmediğini göremeden Chance kalabalıktan bilinmezliğe doğru gider ve film sonlanır.

İlk aşamada Propp'un belirlemiş olduğu ve alana kazandırdığı yöntemiyle Being There filminin analizi yapılarak 31 işlevin filmdeki yansımaları belirlenmiştir. Bu anlamda analizin simgesel gösterimi aşağıdaki şekilde aktarılmaktadır;

Simgesel Gösterim: " $\beta \gamma \delta \varepsilon \zeta \mathrm{D} \theta$ a B C $\uparrow \mathrm{D}$ E F G H I J K $\downarrow$ Pr Rs O L M N Q T U Wº"

Bu veriler doğrultusunda Being There filminde Propp'un belirlemiş olduğu 31 işlevden 28'ine rastlanmıştır. Being There filminde 8., 28. ve 31. işleve yönelik herhangi bir içerik bulunmamaktadır.

Bir sonraki aşama bu işlevlerin yerine getirilmesinde yardımcı olan 7 eylem alanının incelenmesidir. Buna göre;

1. "Saldırganın (ya da kötü kişinin) eylem alanı": Filmde Chance karakterine karşı büyük bir düşmanlık besleyen bir ana karakter yoktur. Ancak film politik bir komedi olduğu için ABD Başkanını temsil eden Bobby karakteri bilinmezliğin vermiş olduğu rahatsızlıktan dolayı sürekli olarak Chance karakteri hakkında bilgi toplamak ve onun bir açığını bulmak ister. Hatta hakkında hiçbir bilgiye ulaşamadığı Chance'in FBı ajanı olduğunu düşünmektedir.

2."Bağışçının (ya da sağlayıcının) eylem alanı": Film içerisindeki anlatılara baktığımızda Chance için büyülü nesne televizyon kumandasıdır. Chance, Eve'in şoförü kendisine çarpınca tedavi teklifini kabul ederek Eve'e eşlik eder. Yolculuk sırasında televizyon kumandasını kaybettiğini fark eder ve Eve'e evlerinde televizyon olup olmadığını sorar. Böylece bağışçının desteği sayesinde büyülü nesneye varış temsil edilmiş olur. Bir diğer bağışçı ise Eve'in eşi Benjamin'dir. Chance'in konuşmalarından etkilenen Benjamin onu başkanla tanıştırarak hayatının tamamen değişmesine yol açar.

3."Yardımcının eylem alanı": Filmle birden fazla yardımcının eylem alanı bulunmaktadır. Yaşlı adam Chance'i doğduğu andan itibaren evine almış ve ona bir hayat vermiştir. Louise, Chance'in uzun yıllar yardımcılığını yapmıştır. Dr. Robert ise Chance hakkındaki tüm gerçeği öğrendikten sonra kimseye bir şey söylemeyerek ona yardım etmiştir. 
4. "Prensesin (aranan kişi) ve babasının eylem alanı": Filmde Eve'i prensesin eylem alanına dâhil edebiliriz ancak bir baba figürü ve eylem alanı bulunmamaktadır.

5. "Gönderenin eylem alanı": Benjamin, senatörün verdiği davete kendisinin yerine eşi Eve ile birlikte Chance'in katılmasını ister.

6. "Kahramanın eylem alanı": Film Chance karakteri üzerine kurgulanmıştır. Chance sadeliği, doğallığı ve söylemleriyle aslında hiçbir eğitim almamasına rağmen birçok zümreden insanın kendisini referans alacağı bir kahraman olarak yansıtılmaktadır.

7. “Düzmece kahramanın eylem alanı": Filmin ilk sahnelerinde karşımıza çıkan Avukatlık bürosu memuru Thomas'ı bu eylem alanına dâhil etmek mümkündür.

Ayrıca 31 işlev ve 7 eylem alanının film içerisinde karışık bir şekilde karşımıza çıktığı görülmektedir. Romanlar yapısı gereği çok çeşitli ve karmaşık olay örgüsüne sahiptir. Bu yüzden işlevlerin ve eylem alanlarının her zaman aynı doğrusal düzlemde aktarılamayacağı Propp'un da belirttiği noktalardan birisidir. Being There filminde Propp'un belirlediği 7 eylem alanına yönelik sahneler bulunmaktadır. Ancak bu eylem alanlarının tam olarak yansıtıldığını söylemek yanlıştır. Filmde aranan kişi ve babasının eylem alanına doğrudan rastlanmamıştır. Filmin geneli değerlendirildiğinde uygun olabileceği düşünülen eylem alanları örnek olarak verilmiştir.

\section{Tartışma ve Sonuç}

Bireyleri ve toplumları anlamanın ve anlamlandırmanın yollarından birisi olan anlatılar kültürel yaşamımızın temel unsurlarındandır. Sözlü gelenekte insanların hikâye anlatma intiyacıyla ortaya çıkan masallar çağlar boyunca farklı araç ve yöntemlerle günümüze ulaşmıştır (Çakır, 2017, s. 134). Masalların yazı ve matbaa ile birlikte basılı bir eser olarak yaygınlaştırılması bu yöntemlerden biridir. Öte yandan masalların yaygınlaşmasında kitlelerin iletişimini sağlayan görsel, işitsel ve dijital araçların da etkisi büyüktür. Masallar bu araçlarda dizi, film, reklam formatında bireylere ve toplumlara ulaştırılmaya devam etmektedir. Ancak sadece masallar değil diğer edebî yapıtlar da bu formatlara uyarlanarak hedef kitleye ulaştırılmaktadır. Son dönemlerde özellikle klasikleşmiş yapıtların yanı sıra günümüze yakın zamanlarda okuyucunun beğenisine sunulmuş ve ilgi görmüş birçok edebi yapıtın da (Harry Potter, Yüzüklerin Efendisi, Alacakaranlık vb.) sinemaya uyarlandığını söylemek mümkündür. Sinema filmleri, ait oldukları dönemin tarihî dokusuna yönelik ayırt edici özelliklere sahip unsurlar içermektedir. İzleyiciler filmlerin olay örgüsünde bulunan işaretleri ve görüntüleri yorumlarken aynı zamanda filmin kendisi için ne anlam ifade ettiği üzerine de düşünmektedir (Burgoyne, 2011, s. 126). Bu düşünme sürecinde imgeler, göstergeler ve semboller etkili olmaktadır. 
Çalışma kapsamında yöntem olarak Vladimir Propp'un biçimbilimsel çözümleme (masalın biçimbilimi) yöntemi kullanılmış olup yöntemin sinema alanında kullanımına yönelik bir inceleme yapılmıştır. Propp, 1915-1930 yılları arasında masallar üzerinde biçimbilimsel çalışmalar yaparak Rus masallarını analiz etmiştir. Bu noktada sorulması gereken soru: "Propp günümüzde yaşasaydı bu yöntemini çok daha geniş alanlara yayılacak şekilde yeniden gözden geçirir miydi?" Şüphesiz ki bu soru cevaptan yoksundur. Ancak masalların işlevlerinin ve eylem alanlarının belirlendiği bu yöntem yıllar sonra dizi, film, reklam, afiş, roman ve hikâye çözümlemelerinde kullanılmıştır. Hatta birçok film ve dizinin senaryosu edebî yapıtların doğrudan ya da dolaylı uyarlamasıyla oluşturulmaktadır.

Örneklem olarak seçilen Being There, Polonya asıllı Amerikalı yazar Jerzy Kosinski'nin 1971 yılında yayımladığı politik komedi romanıdır. Being There, "Bir Yerde" olarak çevrilmektedir. Bu isimle anlatılmak istenen "doğru zamanda doğru yerde olmak"tır. Roman yayınlandıktan 8 yıl sonra sinema uyarlaması yapılmıştır. Romandan uyarlama bir film olan Being There'in biçimbilimsel çözümleme yöntemiyle incelenmesi film analiziyle birlikte romanların da analizinin yapılabileceğine yönelik zemin hazırlamıştır.

Being There filminin biçimbilimsel çözümlemesi 31 işlev ve 7 eylem alanı üzerinden gerçekleştirilmiştir. Bu bağlamda elde edilen veriler değerlendirildiğinde Being There filminde 28 işlev ve 7 eylem alanı bulunmaktadır. 8. işlev olan kötülük, 28. işlev olan ortaya çıkarma ve 31. işlev olan evlilik işlevlerine filmde rastlanmamıştır. Propp'un yönteminde ortaya koyduğu en önemli tez masallarda bulunan işlevlerin belirli bir sırasının bulunduğu ve olayların bu sıralama doğrultusunda gerçekleştiğidir. Propp tüm işlevlerin masalda bulunmasa da var olan işlevlerin masalın iskeletini koruduğunu savunmaktadır. Being There filminde eksik olan iki işleve rağmen biçimbilimsel çözümlemede bir eksiklik bulunmamaktadır. Ancak incelenen sinema filminde Propp'un biçimbilimsel çözümleme yöntemiyle çelişen en önemli unsur işlevlerin sıralanışıdır. Being There filminde belirlenen işlevlerin Propp'un sıralaması çerçevesinde gerçekleşmediği saptanmıştır. Yani Propp'un belirttiği gibi işlevler birbirini takip eden bir yapıda değildir.

Filmler yapısı gereği alışılageldiğimiz olay örgüsünün dışına çıkabilmektedir. Being There bir romandan uyarlanan sinema filmidir. Sinema filminde kitapta yer alan her detaya yer verilmediği görülmektedir. Kahramanların isimleri ve işlevleri, olay örgüsünün genel akışı kitapla uyumlu olsa da biçim bilimsel çözümlemede kolaylık sağlayacak bazı ayrıntılara değinilmemiştir. Bir anlatıyı okumak ve o anlatıyı izlemek arasında farklılıklar bulunmaktadır. Yapıtın vermek istediği mesajlara bağlı kalınarak yapımcılar tarafından senaryoda eklemeler ve çıkarmalar yapılmaktadır. Bazen verilmek istenen mesaj en son sırada yer alırken bazen filmin ilk sahnelerinde aktarılabilir. Örneğin; "kahramanın yardımına koşulur" işlevi 22. sırada gerçekleşmekte- 
dir. Filmde bu işleve örnek olan iki sahne bulunmaktadır. İlk örnek filmin başlangıç sahnelerinde gerçekleşirken, ikinci örnek filmin son sahnelerinde gerçekleşmektedir. Örneklem olarak seçtiğimiz filmde Propp'un belirlediği işlevler ve eylem alanları bulunmakta olup sıralanış Propp'un belirlediği şekilde gerçekleşmemektedir. Bu durum bize Propp'un biçimbilimsel çözümleme yönteminde olmazsa olmaz kurallarından birinin sekteye uğradığını göstermektedir.

Genel bir değerlendirme yapmak gerekirse Propp'un yöntemini olağanüstü kısa masallar üzerinden oluşturmasının en önemli gerekçesi kısa özellik gösteren olağanüstü masallarda olay örgüsü ve kahramanların eylem alanlarının sınırlı olmasıdır. Ancak dizi ve film gibi çok renkli ve uzun metrajlı yapımlarda olay örgüsü ve eylem alanları masala göre daha kapsamlıdır. Örneğin masallarda bir ya da ekseriyetle birden fazla kötü karakter bulunurken filmlerde bunun sayısı artabilmektedir. Ayrıca filmler kitle kültürünün beğenisine sunulduğu için çoğunlukla senaryo oluşturulurken ilgiyi ve merakı arttırmak için filmin ilk dakikalarında işlevler ve eylem alanları açık bir şekilde servis edilmemektedir. Bu durumda bize Propp'un yöntemini niçin sadece olağanüstü masallarla sınırlandırdığını açıklamaktadır. Çünkü masallarda olaylar belirli sıralamaya göre gerçekleşir. Çağdaşlarının da belirttiği gibi bu yöntemde yer alan 31 işlev ve 7 eylem alanı incelenecek olan ürünün yapısına göre yeterli olurken bazen eksik kalmaktadır.

Bu çalışmada işlev ve eylem alanlarının çoğu saptanmış olmasına rağmen yöntemin beklentilerinin tam anlamıyla karşılanmadığını söylemek mümkündür. Eğer Propp'un biçimbilimsel anlatı çözümlemesi her türde sorunsuz bir şekilde uygulanıp karşılık bulmuş olsaydı, ürünlerin yaratıcılıklarını ve içeriksel çeşitliliğini sorgulamamız gerekirdi. Yöntemin en büyük sorunlarından birinin işlevlerin sıralanışındaki değişmezlik vurgusu olduğu düşünülmektedir. Çünkü yapılan birçok analizde işlevler ve eylemler bulunmakta ancak sabit değişken olarak sıralı bir şekilde karşımıza çıkmamaktadır. Propp'un biçimbilimsel analizi alanında ilk olma özelliği göstermekle birlikte yeni dönem araştırmacıları tarafından eksik yönleri bulunmakta, modelin geliştirilmesine yönelik yeni bakış açıları oluşturulmaktadır. 


\section{KAYNAKÇA}

Abalı, i. (2013). Yapısal folklor kuramı bağlamında bir masal incelemesi örneği. ídil Dergisi, 2(10), 26-40.

Bars, M.E. (2014). Vladimir Propp'un yapısal çözümleme yöntemi çerçevesinde Battal Gazi Destanı filminin incelenmesi, Tarih Okulu Dergisi (TOD),7(XVIII), 79-97.

Ben-Amos, D. (1972). Formal or structural studies of traditional tales: The usefulness of some methodological proposals advanced by Vladimir Propp, Alan Dundes, Claude Lévi-Strauss and Edmund Leach by Bertel Nathhorst. The Journal of American Folklore, 85(335), 82-84.

Burgoyne, B. (2011). The epic film in world culture. Newyork: Routledge.

Cirese, A. M. (1982). Introduction to the historical roots of fairy-tales by Vladimir Ja. Propp. Russian literature. North-Holland Publishing Company, 12(1), 33-44.

Çakır, S. (2017). Yeşilçam sineması ve masal formu: Ayşecik. Journal of Turkish Studies (Elektro$n i k), 12(2), 133-150$.

Dobie, A. B. (2012). Theory into practice: An introduction to literary criticism. Boston: Wadsworth, Cengage Learning.

Doğan, E. (2018). Türk sinemasında masal uyarlamaları ve Vladimir Propp'un halk masalları işlevlerinin Pamuk Prenses ve Yedi Cüceler (1970) filminde çözümlenmesi. Journal of Turkish Studies (Elektronik),13(23), 53-67.

Kılıç, E.G. (2018). Farklı yüzyıllar aynı biçimler: V. Propp'un işlevsel yaklaşımı çerçevesinde Alacakaranlık film serisi üzerine bir çözümleme ve kitle kültürü sineması eleştirisi. International Journal of Social Sciences and Education Research, 4(3), 467-482.

Knyf, K. (2009). Exploring faerie: A framework for the fairy tale film. Carleton University. Ottawa, Ontario. Master of Arts: M.A.

Lahlou, K. (2017). An attempt at applying Vladimir Propp's morphology of the folktale on Charles Dickens's great expectations. AWEJ for Translation \& Literary Studies, 1(3), 106-120.

Levi-Strauss, C. (1983). Structural anthropology volume 2, (M. Layton, Çev.). Chigago: The University Of Chigago Press.

Lotman, Y. M. (2012). Sinema göstergebilimi. (O. Özügül, Çev.). Ankara: Nirengi Kitap.

Özçalışkan, Ş. (1996). Vladimir Proppıun biçim bilimsel yaklaşımı çerçevesinde bir Keloğlan masalının incelenmesi. Dilbilim Araştırmaları Dergisi, 7, 59-75. Retrieved from http://dad.boun. edu.tr/tr/pub/issue/4533/62334.

Propp, V. (2001). Masalın biçimbilimi -olağanüstü masalların yapısı- (M. Rifat \& S Rifat, Çev.). İstanbul: OM Yayınevi. 
Propp. V. (1998). Folklor/teori ve tarih (N. Hasgül \& T. Tanyel, Çev.). Avesta: İstanbul.

Rifat, M. (1998). XX. yüzyılda dilbilim ve göstergebilim kuramları. İstanbul: YKY.

Rifat, M. (2009). Göstergebilimin ABC'si. İstanbul: Say Yayınları.

Rifat, M. (2013). Açıklamalı göstergebilim sözlüğü. İstanbul: Türk İş Bankası Kültür Yayınları.

Stam, R., Burgoyne, R. \& Flitterman-Lewis, S. (1992). Nuevos conceptos de la teoría del cine. Barcelona: Paidós.

Şimşek, G. (2012) Los Angeles'da bir Külkedisi: Propp'a göre bir film çözümlemesi. Erzincan Üniversitesi Sosyal Bilimler Enstitüsü Dergisi, 5(2), 311 - 324.

Todorov, T. (2014). Poetikaya giriş (K. Şahin, Çev). istanbul: Metis.

Türk Dil Kurumu Sözlükleri. (2021). Retrieved from https://sozluk.gov.tr/.

Uğur, U. \& Günaydın, R. (2019). Vladimir Propp'un yapısal çözümleme yöntemi çerçevesinde "Tadeo Jones 2: Kral Midas'ın Sırrı" filmi incelemesi. Nevşehir Hacı Bektaş Veli Üniversitesi SBE Dergisi, 9(1), 25-43.

Yücel, T. (2005). Yapısalcılık. İstanbul: Can Sanat Yayınları.

Yen, A. (1973). On Vladimir Propp and Albert B. Lord: their theoretical differences. The Journal of American Folklore, 86(340), 161-166. 